\title{
Tax Information, Administration and Knowledge on Tax Payers' Compliance of Block Moulding Firms in Ekiti State
}

\section{Clement Olatunji Olaoye, Abiodun Rafiat Ayeni-Agbaje, Abiola Peter Alaran-Ajewole}

Department of Accounting, Faculty of Management Sciences, Ekiti State University, Ado-Ekiti, Nigeria

\section{Email address:}

clement.olaoye@eksu.edu.ng (C. O. Olaoye), abiodunvictory@yahoo.com (A. R. Ayeni-Agbaje), abiolapeter2000@gmail.com (A. P. Alaran-Ajewole)

\section{To cite this article:}

Clement Olatunji Olaoye, Abiodun Rafiat Ayeni-Agbaje, Abiola Peter Alaran-Ajewole. Tax Information, Administration and Knowledge on Tax Payers' Compliance of Block Moulding Firms in Ekiti State. Journal of Finance and Accounting. Vol. 5, No. 4, 2017, pp. 131-138. doi: $10.11648 /$ j.jfa.20170504.12

Received: March 23, 2017; Accepted: April 19, 2017; Published: June 14, 2017

\begin{abstract}
This study examined the impact of tax information, administration and knowledge on tax payers' compliance of Block Moulding Firms in Ekiti State, Nigeria using a survey research design. The data obtained from questionnaire were analysed using the ordinary least square regression method. The results showed that tax information and knowledge had positive significant impacts on tax compliance while tax administration had an insignificant impact on tax compliance with unstandardized beta coefficients of $0.251(\mathrm{t}=2.038, \mathrm{p}<0.05), 0.322(\mathrm{t}=3.682, \mathrm{p}<0.05)$ and $0.077(\mathrm{t}=1.021, \mathrm{p}>0.05)$ accordingly. Thus, the study indicated that tax information, tax knowledge has higher tendency to promote tax compliance than tax administration. The study recommended that government should through its agencies educate the potential tax payers on tax laws and regulations by direct free symposia and seminars.
\end{abstract}

Keywords: Tax Information, Tax Administration, Tax Knowledge, Tax Compliance

\section{Introduction}

The administration and management of taxes in nation building is very important. The importance of tax to the smooth running of government cannot be over-emphasised. They are essential ingredients in building a viable economic prosperity. Taxes and tax system are required for state capacity building for meaningful economic development. The main objective of any tax administration is to collect taxes and duties payable according to the laws of the land. Strong tax administration is a requisite for ensuring high compliance and administering tax policies efficiently. A good tax administration is premised upon a well-designed tax system and strong technical capacity. "Tax is a charge imposed by government authority upon property, individuals, or transactions to raise money for public purposes [39]”. [9], define tax as a compulsory levy imposed by government on individuals and companies for the various legitimate functions of the state. Tax is that part of the property and labour of the citizens, taken by the nation, in the exercise of its legitimate rights, for the support of her government in the discharge of its legitimate functions of maintaining peace and order.

Taxation is seen as a burden which every citizen must bear to sustain his or her government because the government has certain functions to perform for the benefits of those it governs. In developing countries, non-compliance of tax is a serious challenge facing income tax administration and hindering tax revenue performance. "Despite the various tax reforms undertaken by successive governments to increase tax revenue over the years, prior statistical evidence has proven that the contribution of income taxes to the government's total revenue remained consistently low and is relatively shrinking [5]". The taxpayers are, however, not willing to comply when it comes to the obligations imposed on them by law to pay and remit taxes.

A key component of any tax system is the manner in which it is being administered. No tax is better than its administration, so tax administration matters a lot [10]. An essential objective of tax administration is to ensure the maximum possible compliance by taxpayers of all types with their tax obligations. In many developing countries, tax administration is usually weak and characterized by extensive evasion, corruption and coercion. In many cases, 
overall tax compliance levels are low and large proportion of the informal sector of the economy escapes the tax net entirely [11].

Ekiti State is not an exception when it comes to the tax administration and ensuring tax compliance from her relatively large informal sector compared to the other sources of revenue accruing to the state. Ekiti state, located in the south-western part of Nigeria was created on October 1, 1996 from the old Ondo State. It has 16 Local Government Areas with Ado-Ekiti as the state capital. Ado-Ekiti has witnessed a rapid springing up of small scale enterprises within the last 20 years of its existence. Block Making Industry is one of the fastest growing small scale businesses in the state, especially in Ado-Ekiti. The number of block making industries in AdoEkiti was less than ten when the state was created in 1996; the number has increased to over three hundred and fifty sited in Ado-Ekiti alone. This has in a way helped to employ about three thousand, five hundred youths who would have been roaming the street without gainful employment. Besides, the socio-economic effect of this is that these people standard of living have been improved so also their immediate and extended family. By extension, government revenue ought to have increased by the tax these workers of Block Making Industries would pay to the government. Unfortunately, government pays no attention to this set of people perhaps because of the meagre amount of money involved.

How has tax information, administration and knowledge affected this set of people complied with the tax rules and regulations? Tax compliance is the ability and willingness of taxpayers to comply with tax laws, declare the correct and true incomes in each year and pay the right amount of taxes on time. [8] considered tax compliance as the taxpayers' willingness to obey tax laws in order to attain economic development and goal. On the other way round, tax compliance requires a degree of honesty, adequate knowledge of tax and capability to use this knowledge, timeliness, accuracy, and adequate records in order to complete the tax returns and associated tax documentation [50]. [40] described tax compliance as the process of fulfilling the tax payer's civil obligation for tax payment and filing of tax returns including the provision of necessary documents and explanations required by the tax authority in a timely manner. Achieving high levels of voluntary tax compliance and/or maintaining current compliance rates as well as increasing the marginal levels are issues of concern to fiscal policy makers in developed and developing countries. This is the case because, irrespective of the nature of the economy, the principal objective of taxation is to raise revenue towards the financing of public goods and services, and defrayment of government expenditures [30]. Tax compliance is a voluntary submission of oneself to various machineries of tax laws.

Small Scale Enterprises (SSEs) are small businesses that employ a small number of workers and do not have a high volume of sales. Such enterprises are generally privately owned and operated sole proprietorships, corporations or partnerships. SSEs being profit generating establishments are also expected to pay tax. The individual SSE pays a very small amount of tax compared with what the larger establishment would pay and so tax authorities tend to give the larger corporations more attention. This suggests that a good number of SSEs evade taxes that would have otherwise been invested in developmental projects that would have benefitted them (SSEs). Tax compliance is currently a topical issue in Ekiti State as governments at various levels are seeking ways to improve efficiency in tax revenue collection to finance their budgets. Small Scale Enterprises (SSEs) are the majority business taxpayers in most developing countries and as such their compliance levels directly impact on government tax revenue collections in meeting government deficit budget.

Tax compliance is a major problem for many tax authorities. It is not an easy task to persuade taxpayers to comply with tax requirements even as the tax laws are not always precise in some respects [25]. Taxpayers always tend to avoid or reduce their tax liability either through tax evasion or tax avoidance. This may give rise to nonregistration or incorrect filling of their tax returns and loss of revenue to the government. An unduly complex regulatory system and tax regime enforcement makes tax compliance unduly burdensome and often have a distortionary effect on the development of small and medium scale enterprises (SMEs) as they are tempted to change into forms that offer a lower tax burden or no tax burden at all [31] and consequently results in a tax system that imposes high expenses on the society. A poorly executed tax system also leads to low efficiency, high collection charges, and waste of time for taxpayers [15]. Small Scale Enterprises usually have to operate in an overbearing regulatory environment with the plethora of regulatory agencies, multiple taxes, cumbersome importation procedure and high port charges that constantly exert serious burden on their operations [28]. Existing empirical evidence clearly indicates that small and medium sized businesses are affected disproportionately by these costs when scaled by sales or assets. The compliance costs of SMEs are higher than the formal businesses [52]. This potential source of high revenue to the government, the small scale enterprises are aware of the high cost of tax compliance, has devised means of manipulating the system to reduce tax liability or evade the payment of tax.

"The tax system that is perceived as unfair by the citizens has encouraged them to engage in non-compliant behaviour [19]". [1] noted that the state of decay in Nigeria's public infrastructure and economic activity are a reflection of poor public governance with the low tax morale and noncompliance may have become the aftermath effect. In Ekiti State, the income tax compliance has been constrained by the significant number of changes to the tax laws, that are now so complex and only a handful of tax experts can understand them. This creates additional problems for compliance by different categories of taxpayers' who do not have access to sophisticated tax specialists [34].

It is generally believed that taxation is the bedrock of any 
government economic prosperity. Tax administration plays a key role in determining the level in which the objective of taxation is realised. A lot of factors affect the low level of tax compliance in Ekiti State, such as attitudes, income, education, knowledge and age of the taxpayers, corruption, high marginal tax rates, lack of information and nonavailability of financial records, a large informal sector, weak regulatory systems, ambiguity in the tax laws, the existence of non-adherent culture, type of small scale enterprise and the ineffectiveness of tax administration [25]. The imposition and collection of taxes on the block making industries in Ado-Ekiti are faced with administrative challenges such as lack of proper records, non-availability of operational vehicles, ignorance of tax laws, corruption and others.

Hence, this study aims to determine the influence of tax information, tax administration and tax knowledge on the degree of tax compliance of block making industries in AdoEkiti metropolis.

\section{Literature Review}

[12] defined tax compliance as filing all required tax returns at the proper time and that the returns accurately report tax liability in accordance with the tax code, regulations and court decisions applicable at the time the return is filed. A review of the literature shows that [6] conducted the first study of the theoretical model of tax noncompliance. This theoretical model is known as an economic deterrence model [8]. The model assumes rational behaviour among taxpayers' and suggested that tax rate, probability of detection and penalty rate are determining factors that affect tax compliance. Tax compliance can be described as the degree to which a taxpayer obliges to tax rules and regulations. [24] opined that tax compliance is the willingness of individuals and other taxable entities to act in accordance within the spirit as well as the letter of tax law and administration without the application of enforcement activity.

To tackle the challenge non-compliance of tax, it is necessary to understand factors influencing individual's decision to comply with provision of tax laws. The early researchers such as [6]; [8]; [38] based their work on economic perspective of tax compliance and they identified tax rate, penalty and detection probability as factors influencing taxpayers' behaviour. [38] asserted that taxpayers' behaviour of non-compliance depends on their belief of the probability of being detected through an audit and the severity of legal penalties imposed. The structural factors, which are beyond the taxpayers' control, are usually exogenously determined. For instance, tax administration, tax complexity, tax rate structures and audit possibility [7].

Figure 1 shows the interrelationship among the various determinants of tax payers' compliance. Prominent among them are: the taxpayers' access to information, tax knowledge, tax complexity, tax officials' attitude to work and tax administration. Others are tax fairness, tax responsibility, tax burden, tax compliance cost, and demographic characteristics of tax payers.

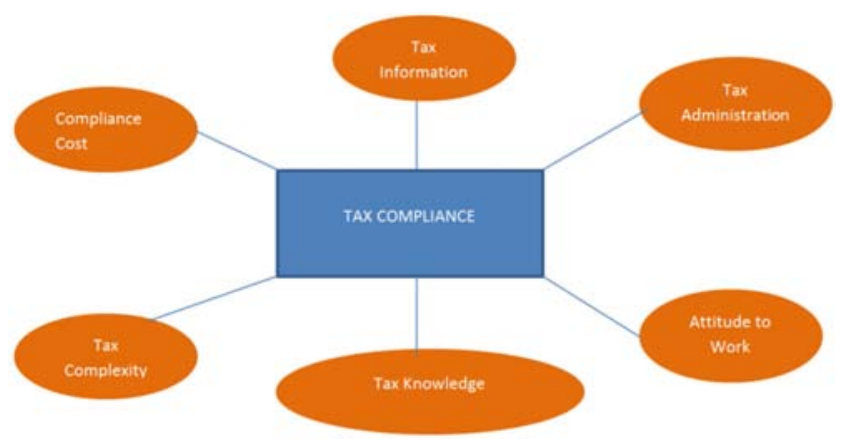

Figure 1. Determinants of Tax Compliance.

\subsection{Factors Affecting Tax Compliance}

The factors affecting the tax compliance are as follows:

Tax Complexity: Tax complexity is another identifiable importance of taxpayers' compliance variable that influences compliance behaviour and it may be the genesis of tax avoidance [23] and [48]. Moreover, [27] stressed that tax laws are too complicated for taxpayers' to keep abreast considering the frequent changes in the tax law. The authors perceived tax complexity as complication in the tax law and frequent changes in the law. These issues may possibly be the reasons why some corporate taxpayers' deploy the services of external tax professionals when they experience difficulties in tax issues [47].

However, [23] found that corporate taxpayers perceived tax computation, tax ambiguity and record keeping as tax complexity. Even though, the taxpayers ought to understand the tax complexity. In another study conducted by [46] it was noted that taxpayers' are aware and compliant with their respective responsibilities. In contrast, the argument by [27] argued that when the tax laws are complex and tedious the taxpayers' may find it difficult to comprehend. This is compounded more when the taxpayers' have no knowledge on tax related issues. In the other argument by [23] which pointed out that tax computation, records keeping and ambiguity are complicated to the taxpayers. Tax payers have to understand the process before they would be able to do the tax computation as well as record keeping. If both arguments are critically analysed, it all lies on tax knowledge because both tax law and computation of tax and others cannot be feasible without tax knowledge. Moreover, [42] found that "simplification of tax is likely to lead to significant economic resource saving". The taxpayers' and the tax authority need to stand up to these challenges and face it squarely. Tax education is important for tax compliance, it is also important for the tax authority to seriously look into the issues of tax knowledge and other compliance variables for effective tax compliance. However, [12] found that tax complexity has a positive relationship with tax knowledge and compliance behaviour.

Tax Administration: This is the way and manner that taxpayers are assessed and are made to pay their taxes due to the government. The tax administration is vested in 
government agency that is charged with the responsibility of assessing, collecting and monitoring tax payers' compliance with the tax laws and regulations. [29] opined that administration lacks a coherent body of literature or set of principles within which well-defined schools espouse particular intellectual positions. Instead, tax administration is a loosely defined area that embraces law, public administration, sociology, and psychology as well as economics. Tax administration should take into cognisance the peculiarity of the environment in which it is operating and adopt the best suited strategies that would ensure easy compliance of the taxpayers.

Tax Fairness: Tax fairness as perceived by [23]; [46] could either be vertical or horizontal fairness. Vertical tax fairness is when taxpayers' are being treated with different rate based on their different business activities. On the other hand, horizontal tax fairness is the instance where taxpayers' are being treated equally in terms of their taxes [32]. Horizontal tax fairness indicates that taxpayers' that are into same business activities and earned same income should probably pay same taxes. [33] found that improved tax fairness would lead to the enhancement of compliance behaviour. The impact of tax fairness which the taxpayers perceived may possibly influence their tax compliance behaviour. Taxpayers' knowledge on tax could be another means that may affect both tax fairness and tax compliance. The attitude of taxpayers' such as tax knowledge and tax complexity influences tax fairness [45]. [51] noted that compliance behaviour and tax fairness has been significantly influenced by the increase in tax knowledge.

Compliance Costs: According to [49], the use of electronic tax registers (ETR) reduces fraudulent accounting, authenticate documents, reduce paperwork and improve management of business through electronic connectivity. Numerous questions arise in this regard including how should transaction records be characterized, the appropriate record keeping format and standard, and how detailed should the description be? This challenge assumes an even more pronounced complexity with the SSEs compliance since it is widely believed that tax administration is regressive with the size of the firm, in the sense of taking a larger portion of resources for smaller companies as compared to the larger ones.

\subsection{Cultural and Demographic Characteristics of Tax Payers}

The Fisher model suggests that demographic variables indirectly affect taxpayers' compliance by their impacts on non-compliance opportunities, attitudes and perceptions. A common demographic variable is the taxpayer's age. A positive link between age and taxpayer compliance is reported in [17]. In general, young taxpayers are more willing to take risks and are less sensitive to sanctions. Traditionally, females have been identified with conforming to rules, moral restraints and more conservative life pattern. Education, as a demographic variable relates to the taxpayers' ability to comprehend and comply or not comply with the tax laws. Two aspects of education have been distinguished: "the general degree of fiscal knowledge and the degree of knowledge involving evasion opportunities [20]".

The degree of knowledge and information might be an important factor in the way taxpayers' behave. Better educated taxpayers' are supposed to know more about tax laws and fiscal policies and thus would be in a better position to assess the degree of compliance [26]. However, it should be noted that there might be people with a lower education who have acquired a high knowledge of tax laws [13]. Some taxpayers' might find complexity of tax information more difficult to understand than others [41]. On the other hand, survey findings indicate that less educated taxpayers' are less exposed to tax compliance information and less informed about relevant tax regulations and need assistance more often [46].

More educated people may be less compliant because they better understand the opportunities for avoiding taxes. Fiscal knowledge may positively influence the practice of avoidance [18]. [46] found that compliance is higher in areas with a better educated population and areas with large student populations have low levels of compliance. Furthermore, areas with high levels of poverty and unemployment have a low level of compliance for all groups. An important factor which influences the incentive to seek tax information is the relevance of information.

\subsection{Theoretical Review}

There are various opinions as to the best ways to improve tax compliance. Given the opportunity, a lot of businesses will not pay taxes unless there is a motivation to do so. Some believe that the best way is to increase tax incentives [43] while others believe that the best way is to increase tax penalties. Thus, tax compliance theories are broadly classified into two. They are the deterrence based theory and psychology based theory.

\subsubsection{Deterrence Theory}

This theory places emphasis on incentives. The theory suggests that taxpayers are moral utility maximizers who are influenced by economic motives such as profit maximization and probability of detection. Hence, the taxpayers analyze alternative compliance paths for instance whether or not to evade tax, the likelihood of being detected and the resulting repercussions and then select the alternative way that maximizes their expected after tax returns after adjusting for risk. Therefore according to the theory, in order to improve compliance, penalties for non-compliance should be increased. Thus, there is a theoretical positive relationship between tax penalty and tax compliance. Increase in tax penalty would lead to increase in tax compliance and vice versa.

\subsubsection{Psychology Theory}

Psychology theory posits that taxpayers are influenced to comply with their tax obligations by psychological factors. It 
focuses on the taxpayers' morals and ethics. The theory suggests that a taxpayer may comply even when the probability of detection is low. As opposed to the deterrence theory that emphasizes increased penalty as solution to compliance issues, psychology theory lays emphasis on changing individual attitudes towards tax systems. Thus, one instrument of changing taxpayers' attitude to tax matters is tax education. It is assumed that improved tax education would increase tax compliance and vice versa.

\subsection{Empirical Review}

[4] conducted a study on Tax compliance behaviour of small scale enterprises in Bassa Local Government of Kogi State in North central of Nigeria. A survey design was used and data were gathered from the register of Bassa Local government Area Council. The Krejcie and Morgan sampling technique was used to determine a sample size of one hundred and ninety seven registered taxpayers. The hypotheses were tested using one sample chi-square. Their results showed that taxpayers' social psychological factors have significant influence on tax compliance level and that taxpayers' demographical factors have significant influence on tax compliance level. They recommended that tax authority should take tax education as a routine responsibility and that there should be a stiff penalty on any taxpayer who is found wanting in sharp practices.

[3], carried out a study on Tax knowledge, Penalties and tax compliance in small and medium scale enterprises in Nigeria. The study was conducted using survey design and data were collected through questionnaire and analysed using least square regression method. The results revealed that tax knowledge had positive significant impact on tax compliance while tax penalty had insignificant positive impact on tax compliance. They recommended that that government should encourage taxpayers knowledge about tax laws and principles thereby creating awareness for the mutual benefits of the government and the taxpayers.

[16] conducted a study titled: Income tax compliance among SMEs in Uganda: taxpayers' proficiencies perspective. A cross sectional descriptive survey design was used and data were gathered from 326 out of 377 SMEs from Mbale district. Their study revealed that income tax proficiencies are multi-dimensional and significant predictors of income tax compliance. They recommended that to improve income tax proficiencies in SMEs in Uganda, intensive tax education with practical knowledge should be carried out by Uganda Revenue Authority to the SMEs' personnel involved in tax matters for efficient compliance.

In another development, [2] evaluated taxpayers' attitude and its influence on tax compliance decisions in Tamale, Ghana. The survey responses from questionnaires administered to operators of SMEs in Tamale, were quantitatively analysed. Both descriptive and inferential statistics were applied. Their results indicated that, individuals were highly concerned with the amount of taxes they pay. The rates of income taxes in Ghana were generally perceived to be high. Furthermore, the burden of taxes paid affects the attitudes of individuals and this informs how they evaluate the tax system and consequently their compliance decisions.

[36] assessed factors that affect tax compliance among small and medium enterprises (SMEs) in North West Nigeria. The study was conducted using SMEs in Zaria, North-West Nigeria. It was found that high tax rates and complex filing procedures were the most crucial factors causing noncompliance of SMEs. Other factors like multiple taxation and lack of proper enlightenment were noted as variables affecting tax compliance among the SMEs surveyed only to a lesser extent. Therefore, they recommended that SMEs should be levied lower percentage of taxes to allow enough funds for business development and better chances of survival in a competitive market. The government should also consider increasing tax incentives such as exemptions and tax holidays as these will not only encourage voluntary compliance but also attract investors who are potential viable taxpayers' in the future.

[37] evaluated promoting sustainable tax compliance in the informal sector in Nigeria. The population for this study comprises both tax officials and business owner managers in the south-east region of Nigeria. To gather the primary data for the study, a set of questionnaire was administered to 200 business owner managers and 115 tax officials. The secondary data were sourced from the Central Bank of Nigeria (CBN) statistical bulletin for a time period of 20 years (i.e. 1990-2009). The Pearson Product-Moment Correlation Co-efficient was the statistical technique employed in testing the stated hypotheses. Their findings showed that several causes of tax compliance problem in the informal sector in Nigeria. Some of the causes are high tax rate, inadequate provision of public goods and services, lack of transparency and accountability of public funds, poor funding of tax boards, absence of functional tax audit, lack of reciprocity and legitimacy, ineffective deterrence measures, out-dated tax laws, lack of public trust, and corrupt practices of tax officials. They recommended that the Nigerian government should put the necessary machinery in place to ensure tax compliance in the informal sector.

\section{Method}

The choice of Ado-Ekiti was informed by its strategic location as the nerve centre of Ekiti State and equally serves as the state capital. It is the most developed city in Ekiti State; it is the administrative seat of government machineries. The rate at which BMI spring up in the city necessitates this research from less than ten (10) in 1996 when the state was created to well over three hundred (300) within the space of twenty (20) years of her existence. Prominent among the early ten are: Messrs Fakehinde, Omolayo, Olatunji, Tunde, Petim, etc. Presently, there are seven zones of Block Making Industries in Ado-Ekiti in which each zone has nothing less than fifty BMI on average. The minimum workers in each of these BMIs are 10 and if multiplied by the number of the BMIs in Ado-Ekiti alone. It means over three thousand, five 
hundred young and energetic youths are employed by this category of informal sector.

\subsection{Model Specification}

This section expresses the habit of operators of BMI in Ado-Ekiti towards tax administration (TAD) as a function of tax compliance. The functional relationship is shown in equation (1)

$$
T A C=F(T A I, T A D, T A K)
$$

Where tax information (TAI), tax administration (TAD) and tax knowledge (TAK) are used as function of tax compliance (TAC). This can be expressed in a multiple regression form as follows:

$$
T A C=\beta_{0}+\beta_{1} T A I+\beta_{2} T A D+\beta_{3} T A K+\varepsilon_{t}
$$

$$
\begin{aligned}
& \text { Where } \\
& \text { TAC }=\text { Tax compliance } \\
& \text { TAI }=\text { Tax information } \\
& \text { TAD }=\text { Tax administration } \\
& \text { TAK }=\text { Tax knowledge } \\
& \beta_{0}=\text { Intercept } \\
& \beta_{1}-\beta_{3}=\text { Parameters of the regression } \\
& \varepsilon=\text { error term }
\end{aligned}
$$

\subsection{Method of Data Collection and Analysis}

The research design in this study is survey design. The data was collected majorly through primary source by the administration of questionnaires. The questionnaire consists of four sections. Section A is on the background information of the respondents, section $\mathrm{B}$ centres on the tax administration system in Ado-Ekiti, section $\mathrm{C}$ dwells on the tax compliance of the operators of the BMI in Ado-Ekiti while section $\mathrm{D}$ requests further comments from the respondents bothering on the subject of discourse.

Five-point Likert-style rating scale method of questionnaire was employed in this study ranging from strongly agree of 5-point to strongly disagree of 1-point. The Likert-style rating method of questionnaire design enables numerical value to be assigned to cases for easy quantitative analysis.

The registered Block Making Industries in Ado-Ekiti, Ekiti State constitute the population of this study. A total of two hundred and fifty respondents were randomly sampled from the Block Making Industries in Ado-Ekiti, Ekiti State where each of the BMI has the chance of being selected.. Out of the two hundred and fifty questionnaires administered to BMI operators in Ado-Ekiti, two hundred (200) were retrieved and analysed. The descriptive statistics of the variables as well as the Ordinary Least Square (OLS) multiple regression analysis was carried out to assess the relative predictive power of the independent variables that is tax administration on the dependent variable- tax compliance.

\section{Results and Interpretation}

Table 1. Regression Analysis on the Impact of Tax Information, Administration and Knowledge on Tax Payers' Compliance.

\begin{tabular}{lllll}
\hline \multicolumn{3}{l}{ Model Summary } \\
\hline Model & R & R Square & Adjusted R Square & $\begin{array}{l}\text { Std. Error of the } \\
\text { Estimate }\end{array}$ \\
\hline 1 & $310^{\mathrm{a}}$ & 096 & .082 & 1.70935 \\
\hline
\end{tabular}

a. Predictors: (Constant), TAK, TAD, TAI

Source: Authors Computation, 2016.

Table1 showed that the explanatory variables (Tax Knowledge-TAK, Tax Administration-TAD and Tax Information-TAI) had $31 \%$ relationship with the level of tax payers compliance (TAC) in block industries while the Rsquare indicated that TAK, TAD and TAI only explained $9.6 \%$ variation in TAC while the remaining $90.4 \%$ are explained by variables not captured in the study such as the level of tax penalty, cost of compliance and likelihood of tax evasion detection as explained by deterrence theory,

\begin{tabular}{|c|c|c|c|c|c|c|}
\hline \multicolumn{7}{|c|}{ Coefficients $^{\mathrm{a}}$} \\
\hline \multirow{2}{*}{\multicolumn{2}{|c|}{ Model }} & \multicolumn{2}{|c|}{ Unstandardized Coefficients } & \multirow{2}{*}{$\begin{array}{l}\text { Standardized Coefficients } \\
\text { Beta }\end{array}$} & \multirow{2}{*}{$\mathbf{T}$} & \multirow{2}{*}{ Sig. } \\
\hline & & B & Std. Error & & & \\
\hline \multirow{4}{*}{1} & (Constant) & 10.524 & 1.035 & & 10.171 & 000 \\
\hline & TAI & 251 & 123 & 158 & 2.038 & 043 \\
\hline & TAD & 077 & 076 & 079 & 1.021 & 309 \\
\hline & TAK & 322 & 088 & 253 & 3.682 & 000 \\
\hline
\end{tabular}
taxpayers' morals and ethics values as propounded by psychology theory of taxation and factors ascribed by [37] such as high tax rate, inadequate provision of public goods and services, lack of transparency and accountability of public funds, poor funding of tax boards, absence of functional tax audit, lack of reciprocity and legitimacy, ineffective deterrence measures, out-dated tax laws, lack of public trust, and corrupt practices of tax officials.

Table 2. Regression Analysis on the Impact of Tax Information, Administration and Knowledge on Tax Payers' Compliance.

a. Dependent Variable: TAC.

Source: Authors Computation, 2016.

Based on the table II, it could be inferred that if the explanatory variables (Tax Knowledge-TAK, Tax Administration-TAD and Tax Information-TAI) are held constant, the level of Tax payers compliance-TAC in block industries will be 10.524unit, which implies that in a situation where the potential tax payers do not have knowledge and adequate information on tax administration, the level of tax compliance among tax payers in Block 
making industry will be influenced by 10.524. The unstandardised beta coefficient of Tax Information-TAI is $0.251(t=2.038, p<0.05)$, this implies that an increase in the level of information at the disposition of tax payers about tax administration will result to $25.1 \%$ significant increase in the level of compliance by the tax payers. Tax administration indicated an insignificant $7.7 \%(t=1.021, p>0.05)$ impact on the compliance rate of taxpayers in Block making Industry. Tax payers knowledge on tax administration (TAK) had an unstandardised beta coefficient of 0.322 with a t-value of 3.682 and p-value that is lesser than 5\% level of significance, this signifies that for every increase in the level of tax payers knowledge of tax laws, there will be $32.2 \%$ increase in the level of tax compliance by tax payers as regards filing all required tax returns with respect to tax code, regulations and court decision. The findings of the study are in consonance with [3] which disclosed that tax knowledge had positive significant impact on the level of tax compliance among small and medium scale enterprises in Nigeria and with the view expounded by [26] that the degree of knowledge and information is an important factor in the way taxpayers' behave in terms of the level of compliance.

\section{Conclusion and Recommendations}

The level at which tax payers complied with tax laws in terms of filing of tax returns and remittance are determinants of their level of knowledge and information on tax administration in respect to tax rates, allowance, allowable and non-allowable expenses and penalty for tax default. In other to cover the gap of tax payers' knowledge and information on tax administration in the country especially Ado-Ekiti so as to boost the level of tax compliance, the government through its agencies should educate the potential and prospective tax payers on tax laws and regulations through direct free symposium and seminars, that is a call visit to the block making industries respective union meetings, give them tax incentives, and provision of soft loans. Government should discourage payment of taxes through unions, sanction any official caught engaging in the collection of kick-backs.

\section{References}

[1] Abati, R. (2006, October 13). Nigeria's deplorable roads. The Guardian, p. 2.

[2] Abubakari, A. \& Christopher, J. A. (2013). Evaluating taxpayers' attitude and its influence on tax compliance decisions in Tamale, Ghana. Journal of Accounting and Taxation, 5(3), 48-51.

[3] Adesina, O. O. \& Obazee, U. (2016). Tax knowledge, penalties and tax compliance in small and medium scale enterprises in Nigeria. iBusiness, 8, 1-9. http://www.scirp.org/journal/ib. http://dx.doi.org/10.4236/ib.2016.81001.

[4] Akubo, D., Akowe, A. \& Ayuba, A. (2016). Tax compliance behaviour of small scale enterprises in Bassa local government area of Kogi State. Journal of Good Governance and Sustainable Development in Africa, 3(1), 58-72.

[5] Alabede, O. J., Zainol, A. \& Kamil, M. I. (2011). Determinants of tax compliance behaviour: A proposed model for Nigeria. International Research Journal of Finance \& Economy, 122.

[6] Allingham, M. \& Sandmo, A. (1972). Income tax evasion: A theoretical analysis. Journal of Public Economics, 1(4), 323-338.

[7] Alm, J. Jackson, B. \& Michal, M. (1992). Institutional uncertainty and taxpayer compliance. American Economic Review, 82(4), 1018-1026.

[8] Andreoni, J., Erard, B., \& Feinstein, J. (1998). Tax compliance. Journal of Economic Literature, 36, 818-860.

[9] Arowomole, S. S. A \& Oluwakayode, E. F. (2006). A Classic Introduction to Nigerian Taxation. Lagos: King Julius Educational Publishers.

[10] Bahl, R. and Bird, R. (2008). Tax policy in developing countries: Looking back and forward. National Tax Journal, 297-301. http://dx.doi.org/10.17310/ntj.2008.2.06.

[11] Bautigam, D., Fjeldstad, O. H. and Moore, M. (2005). Taxation and State-Building in Developing Countries: Capacity and Consent. Cambridge: Cambridge University Press.

[12] Doran, M. (2009). Tax penalties and tax compliance. Harvard Journal on Legislation, 46, 111-161.

[13] Eriksen, K. \& Fallan, L. (2006). Tax knowledge and attitudes towards taxation. A Report on quasi-experiment. Journal of Economic psychology, 17(3), 387-402.

[14] Fakile, A. S. (2011). Analysis of tax morale and tax compliance in Nigeria. $\mathrm{PhD}$ Thesis, Covenant University, Otta, Nigeria.

[15] Farzbod, J. (2000). Investigation of the effective factors in the tax efficiency. Unpublished Master's Thesis, Governmental Management Training Centre, Tehran.

[16] Festo, N. T. \& Isaac, N. N. (2013). Income tax compliance among smes in uganda: taxpayers' proficiencies perspective. International Journal of Business and Social Science, 4(11), 133-135.

[17] Fischer, C. M., Wartick, M. \& Mark, M. (1992). Detection probability and taxpayer compliance: A review of the literature". Journal of Accounting Literature. 11, 146.

[18] Gereroms, H. \& Wilmots, H. (1985). An empirical model of tax evasion and tax avoidance. Journal of Public Finance, 40, 190-209.

[19] Gilligan, G. \& Richardson, G. (2005). Perceptions of tax fairness and tax compliance in Australia and Hong Kong: A preliminary study. Journal of Financial Crime, 12(4), 331-343.

[20] Groenland, E. A. \& van Veldhoven, G. M. (1983). Tax evasion behaviour: A psychological framework. Journal of Economic Psychology, 3(2), 129-144.

[21] Internal Revenues Services (IRS). (2009). Update on reducing the federal tax gap and improving voluntary compliance. http://www.irs.gov/pub/newsroom/tax_gap_report_final_version.pdf. 
[22] Internal Revenues Board (IRB) (2000). Self assessment system: IRB guide on tax audit.

[23] Isa, K. M. (2012). Corporate taxpayers' compliance variables under the self-assessment system in Malaysia. (Doctor of Philosophy), Curtin University.

[24] James, S. \& Alley, C. (2002). Tax compliance, self-assessment and tax administration. Journal of Finance and Management in Public Services, 2(2), 27-42.

[25] James, S. and Alley, C. (2004) Tax compliance, selfassessment and tax administration. Journal of Financial and Management in Public Services, 2, 27-42.

[26] Lewis, A. (2010). The Psychology of Taxation. Oxford: Martin Robertson.

[27] Loo, E. C., McKerchar, M., \& Hansford, A. (2010). Findings on the impact of self-assessment on the compliance behaviour of individual taxpayer in Malaysia: A case study approach. Journal of Australian Taxation, 13(1/2), 1-22.

[28] Lumumba, O. M., Migwi, S. W. and Magutu, O. (2010) Taxpayers' attitudes and tax compliance behavior in Kenya: How the taxpayers' attitudes influence compliance behaviour among SMEs business income earners. African Journal of Business \& Management, 1, 112-122.

[29] Mansfield, C. Y. (1988). Tax administration in developing countries: An economic perspective. Palgrave Macmillan Journal, 35(1), 181-197.

[30] Martina, H. Silvia, R. Eric, K. \& Alfred, S. (2008). Procedural fairness and tax compliance. Economic Analysis of Tax Policy, $38(1), 137$.

[31] Masato, A. (2009). Globalization of production and competitiveness of small and medium size enterprises in Asia and Pacific: Trend and Prospects". Publication of United Nation Economic and Social Commission 'for Asia and the Pacific (ESCAP). Studies in Trade and Investment Series Paper, 1-31.

[32] Michael, L. G. (1978). Tax avoidance, horizontal equity and tax reform: A proposed synthesis. Southern Economic Journal, 44(4), 798-812.

[33] Mukasa, J. (2011). Tax knowledge, perceived tax fairness and tax compliance in Uganda: The case of small and medium income taxpayers in Kampala Central Division. Masters Dissertation, Department of Accounting and Finance, Makerere University, Uganda.

[34] Oberholzer, R. (2008). Attitudes of South African taxpayers towards taxation: A pilot study. Accountancy Business and the Public Interest, 7(1), 44.

[35] OECD. (2004). Taxpayers' rights and obligations - Practice note. Tax Guidance Series, 3-5.

[36] Ojochogwu, W. A. \& Stephen, A. O. (2012). Factors that affect tax compliance among Small and Medium Enterprises (SMEs) in North Central Nigeria. International Journal of Business and Management 7(12), 87-96.

[37] Okoye, P. V. C., Akenbor, C. O. \& Obara, L. C. (2012). Promoting sustainable tax compliance in the informal sector in Nigeria. International Journal of Arts and Humanities, 1(1), 40-54.
[38] Oladipupo, A. O. \& Obazee, U. (2016). Tax knowledge and tax compliance in small and medium scale enterprises in Nigeria. iBusiness http://www.scirp.org/journal/ib http://dx.doi.org/10.4236/ib.2106.81001.

[39] Olaoye C. O. (2009). An Assessment of Internally Generated Revenue in Nigeria. International Journal of Pan-African Book Company Cotonu, 2 (3):23-36.

[40] Oyedele, T. (2009). Tax Incentive as Tools for Compliance. Lagos. The Chartered Institute of Taxation of Nigeria.

[41] Pinney, N. A. (1993). Will I be audited? Rational versus cognitive theories of the informed citizen. Ph.D. thesis, University of New York.

[42] Pope, J. (1993). The compliance costs of taxation in Australia and tax simplification: The issues. Australian Journal of Management, 18(1), 70-75.

[43] Riahi-Belkaoui, A. (2004). Relationship between tax compliance internationally and selected determinants of tax morale. Journal of International Accounting, Auditing and Taxation, 13, 135-143. http://dx.doi.org/10.1016/j.intaccaudtax.2004.09.001.

[44] Richardson, G. (2006). Determinants of tax evasion: A cross country investigation. Journal of International Accounting, Auditing and Taxation, 15, 150-169. http://dx.doi.org/10.1016/j.intaccaudtax.2006.08.005.

[45] Saad, N. (2010). Fairness perceptions and compliance behaviour: The case of salaried taxpayers in Malaysia after implementation of the self-assessment system. e-Journal of Tax Research, 8(1), 32-63.

[46] Saad, N. (2012). Perceptions of tax fairness and tax compliance behaviour: A comparative study. Journal Pengurusan, 36, 89-100.

[47] Sapiei, N. S. (2012). External tax professionals' perception of the corporate taxpayers' compliance costs and behaviour under the self-assessment system. Monash University Sunway Campus, Malaysia, Kuala Lumpur.

[48] Sapiei, N. S. \& Kasipillai, J. (2012). External tax professionals'perception of the corporate taxpayers' compliance costs and behaviour under the self-assessment system. Ph. D dissertation, School of Business, Monash University Sunway Campus, Malaysia: Kuala Lumpur.

[49] Slemrod, J. (2007). Cheating ourselves: The economics of tax evasion. Journal of Economic Perspectives. 21(1), 25-48.

[50] Singh, V. and Bhupalan, R. (2001). The Malaysian selfassessment system of taxation: Issues and challenges. Tax National, 12-17.

[51] Tan, L. M. \& Chin-Fatt, C. (2000). The impact of tax knowledge on the perceptions of tax fairness and attitudes towards compliance. Massey University. Dept. of Accountancy and Business Law.

[52] Weichenrieder, A. J. (2007). Survey on the taxation of small and medium-sized enterprises. Draft report on responses to the questionnaire. http://www.oecd.org/dataoecd/52/25/39597756.pdf. 